\title{
INFLUENCE OF PARENTS' SOCIO-ECONOMIC STATUS ON EDUCATIONAL ASPIRATIONS OF STUDENTS IN SPLIT (CROATIA): SOCIOLOGICAL RESEARCH
}

\author{
Gorana Bandalović ${ }^{1}$, Zorana Šuljug Vučica ${ }^{2}$, Antea Mrčela ${ }^{3}$ \\ ${ }^{1}$ Associate Professor, University of Split, Faculty of Humanities and Social Sciences (CROATIA), \\ gbandalo@ffst,hr \\ ${ }^{2}$ Associate Professor, University of Split, Faculty of Humanities and Social Sciences (CROATIA), \\ zorana@ffst.hr \\ ${ }^{3}$ M.A. of Sociology, University of Split, Faculty of Humanities and Social Sciences \\ (CROATIA), amrcela@yahoo.com
}

\begin{abstract}
Numerous studies show that the socio-economic factors significantly affect the child's psychophysical abilities as well as the development of certain values and morals. Socio-economic status is often singled out as a factor of social stratification and as such, directly or indirectly, affects all stages of an individual's education. Regardless of "free" education in Croatia (at primary and secondary school level), socio-economic status is still associated with the possibility of choosing a school, school program and further profiling of students. That is why the aim of this research is to examine the impact of parents 'socioeconomic status on students' educational aspirations. The characteristics of the socioeconomic status examined in this paper are the level of education of the parents, household income, the number of books in the household and reading activities. At the same time, the researchers in this paper examine the extent to which children will follow the parental example and whether parents will impose their wishes and ideas regarding the child's education.

The research was conducted using the survey method in 2020 on a convenient sample of 203 respondents aged 18 to 22 years living in Split (first and second year students of different faculties). The obtained results indicate the existence of a latent socio-economic impact in terms of the level of education of both father and mother, where a higher level of education of parents is associated with a more positive attitude towards university obligations and desires in continuing education. The results show that the division into malefemale occupations is still present in society, with a high percentage of fathers who were educated in technical occupations, while mothers were mostly educated in the social sciences and humanities. There is a correlation between the number of books in the home library and the total number of books that students have read, but the number of read books is not related to the parent's reading habits. However, no direct and intrusive influence of parents on respondents' decisions regarding study and life habits was found.
\end{abstract}

Keywords: socioeconomic impact, students, educational aspirations, sociological research

\section{INTRODUCTION}

The family is the most important institution of the socialization process that shapes individuals from childhood to adulthood. The results of previous research, as Šimić Šašić et al. point out, clearly show that there is a connection between family factors and student success in school. Namely, the initial interests of researchers 
for this topic were mainly focused on sociodemographic characteristics of the family and school success, and then the interest shifted towards the influence of parenting practices and parenting style on student success in school. At the same time, research was conducted on the impact of the wider social context, including culture, on school success and parental behavior. (Šimić Šašić et al., 2011, p. 32). In other words, the interrelationships of family variables (such as parental education, socioeconomic status, place of residence, etc.) and their relationship to school achievement appear to be very complex and specific in terms of student characteristics, degree of academic achievement and wider social context (Šimić Šašić et al., 2011, p. 36).

School success is primarily the result of students' psychophysical characteristics. Success in school is defined as the degree to which students have permanently adopted the curriculum of prescribed knowledge, skills and habits and developed psychophysical abilities (Encyclopedic Dictionary of Pedagogy according to Bedeniković Lež, 2009, p. 331). School success also means adapting students to the social environment (Zloković according to Škorokov, 2014). However, the family is still one of the most important factors in the development of a child's personality and success in school. According to Bedeniković Lež (2009), the influence of the family on school success is manifested through the economic climate in the family, parental education, parenting style, family size and birth order of the child, which overall creates socio-economic impact.

Numerous researchers (Baranović et al., 2014; Gregurović and Kuti, 2010; Ivanović and Rajić-Stojanović, 2012; Lee and Burkham, 2002; Škorokov, 2014) have studied the impact of family socioeconomic status on the success of a child, pupil or student. The mentioned authors are of the opinion that the socio-economic factor significantly affects the psychophysical abilities of the child as well as the development of certain values and morals. Namely, socio-economic status forms the cultural capital of an individual or group, which makes their habitus and provides a certain way and lifestyle (in the present, but also in the future). In most research, socio-economic status stands out as a factor due to which we can talk about social stratification, (in)equality among the belonging strata and gender differences between individuals. It can also be accessed as a tool that can help achieve a meritocratic society (Pavić and Vukelić 2009, p. 55). Accordingly, the socioeconomic status in Croatia directly or indirectly affects all stages of an individual's education. Regardless of "free" education (at primary and secondary school level), socio-economic status is still associated with the possibility of choosing a school, school program and further profiling of students (Gregurović and Kuti, 2010, p. 192).

Socioeconomic status is a sociodemographic characteristic of an individual or group, in this case the family, which is defined as a relative position within the social hierarchy depending on access or availability of funds, power and social prestige (Sirin according to Baranović et al., 2014, p. 286). The socio-economic status of an individual has an impact on all spheres of one's life, including education. The most important predictors of educational success are family income and the education and occupation of parents, which indicate the extent to which the student has access to material resources needed for success in school (Baumert and Schümer according to Baranović et al., 2014, p. 286). "Comprehensive meta-analyzes show that the relationship between socioeconomic status and educational attainment is very stable (White according to Burušić et al., 2010, p. 712) and that parental education is one of the most stable predictors of most socioeconomic status indicators examined" (Schiller et al. according to Burušić et al., 2010, p. 712). More educated parents are more capable to provide better educational opportunities, help the child learn and thus transfer competencies to and teach them the same (Noack according to Đurić, 2015, p. 13). In this regard, the results and analysis of PISA research in Croatia confirmed a significant connection between socioeconomic status and student achievement. Indicators of family environment reflect differences among students, and indirectly describe the characteristics of the wider community through the aggregation of students who come from similar backgrounds (Gregurović and Kuti, 2010, p. 192). Following this, Bedeniković Lež (2009, p. 333) claims that educated parents make greater demands on their children, cooperate better with the school and in less time notice and correct mistakes in upbringing of their children.

This gives rise to certain parental expectations when it comes to school success, as well as the level of parental involvement and the impact of family harmony and parental awareness on the child. Through socioeconomic status, the family lays the foundations for the emotional, social, and moral development of the personality. However, at the same time it creates the foundations for the inclusion of the child in complex social relationships and their understanding and acceptance of desirable social behavior (Bedeniković Lež, 2009, p. 332).

Burušić et al. (2010) emphasize the bidirectionality of parental expectation and child's school results. Analyzing the characteristics of the family, the socioeconomic status of the family proved to be the best predictor of school success in a large number of studies. In other words, those parents who stayed longer in 
the education system, thus achieving a higher level of education, can expect that their descendants will achieve better results in the educational context. On the other hand, those who have left system of education earlier can expect that their descendants will have lower achievements in the educational context (Burušić et al., 2010, p. 711). However, it is also possible that parents of lower socio-economic status will have high expectations regarding the child's level of education. Such a case is called "getting out of the vicious circle of poverty" where in a family of lower socio-economic status, education is still highly valued as a way to shift social status (Baucal, 2012, p. 19).

Parental involvement and interest in school activities are examined according to several criteria. These are the amount of parental involvement, its quality and type. The amount of involvement is the time that both parents or one of them actively spends playing or talking to the child or teaching the child. One of the most consistent results in research on parental involvement is the established link between parental education and inclusion. Thus, it has been shown that more educated parents take more and better care of their children (Sayer et al. according to Bedeniković Lež, 2009, p. 333). Rajeswari and Usha (2014) argue that the higher the family income, the greater the parental involvement in the child's education. Analyzing the results of some research, Bedeniković Lež (2009) points out that it is possible to distinguish three types of parental involvement: 1. direct work on school assignments, ie helping the child directly in school tasks; 2 . indirect work with the child outside school assignments ie dealing with the child in free time and creating opportunities for learning in extracurricular and extracurricular activities; 3. cooperation with the school, ie actively seeking or maintaining cooperation with the teacher or school. The author points out that the results of this research showed that each form of parental involvement increases the motivation to learn, work and engage in school obligations in children, and that students whose parents showed interest in their learning and work achieved better results and sought additional sources of knowledge. It is not important how much time a parent spends with a child but how he/she spends it (Bedeniković Lež, 2009, p. 334).

The average achievements of children are clearly related to the educational level of parents, ie they are negatively associated with early leaving of the school, and therefore have significant social implications. These implications are primarily related to possible interventions in education policy. Interventions should try to eliminate or to some extent eliminate the negative effects associated with the reduced educational level of the environment from which individual students come. There are clear assumptions that greater inclusion of children from low-education families in the school system (through, for example, full-time attendance or additional school activities) could mitigate the negative impacts of a non-stimulating family environment (Burušić et al., 2010, p. 723).

Rajeswari and Usha (2014), emphasizing the importance of family income as a factor in parental involvement, also point to the need to introduce special programs that should raise awareness among parents of "weaker" backgrounds and the importance of parenting in children's education. Improving education among the weaker sections of society should be oriented towards poverty reduction, initiating of regular incomes and permanent employment, which would ultimately help their children enroll in better colleges. There is also possibility of the organization of a campaign to raise parents' awareness of the importance of education, as one of the measures. Furthermore, another way to raise awareness is to hold regular meetings for parents, as well as to share homework with students that would encourage parents to actively participate in the child's education (Rajeswari and Usha, 2014). In other words, the research of parent-child relationship (regarding children's educational aspirations and achievements) proves that parents should just provide sufficient material conditions for their children because that is enough to improve their academic performance. By contrary, "a positive parent-child relationship and family atmosphere should also be built based on material conditions and educational investment " and it would increase the child's motivation for learning, reading and acquiring knowledge (Chen et al. 2018, p. 9)

Increasing parents' awareness of the importance of education could encourage involvement of the parents in the curriculum. According to school regulations, cooperation with the school is mandatory, and there is also a large amount of research documenting the connection between child achievement and parental involvement (Daniel according to Miljević-Riđički et al., 2011, p. 166). However, not enough attention in research is put on some aspects of school-parent collaboration. One of these aspects is the environment in which the school is located (Miljević-Riđički et al., 2011, p. 166). Thus, for example, Bauch emphasizes the connection between the degree of parental participation or satisfaction with school and belonging to an urban or rural environment. For example, smaller but better connected rural areas increase the involvement of parents in their children's lives, as well as in their upbringing and education, which provides them with advantages over schools in large cities (Bauch according to Miljević-Riđički et al., 2011, p. 166). Also, the results of research conducted by Miljević-Riđički et al. (2011) show that better mutual acquaintance between parents and teachers in smaller places leads to better cooperation with the school than is the case in urban areas. On the 
other hand, their research show that in general, parents in Croatia (regardless of the area) almost completely accept the partnership between parents and school, but some segments of school life are seen exclusively as parental work or school work. Therefore, they separate certain types the cooperation.

By overviewing different perspectives on the ways and mechanisms of how the social economic status of a family affects the child's academic behavior and achievements, authors Li and Qiu (2018) in their work have stressed the following aspects. First, human capital theory pays more attention to the role of the economic resources of family and educational investments in child's education. Second, cultural capital and social capital theory stresses the role of parent's educational level and their participation in child's academic education and success. Third, the perspective of school quality argues that the social economic status of a family affects child's educational achievements as well as a chance of continuing schooling through affecting school qualities. In sum, "the impacts of any type of factors cannot exist independently" because family economic resources, environment and school qualities are important and can be perceived as "exogenous factors" that only have effect through pupils'/students' behaviors and academic achievements (Li and Qiu, 2018, p. 4).

\section{METHODOLOGY}

\subsection{Research Objectives and Hypothesis}

The overall goal of the research is to examine the impact of parents' socioeconomic status on students' educational aspirations. The characteristics of socioeconomic status examined in this paper are the level of education of parents, household income, number of books in the household and reading activities. The specific objectives are to examine the connection between a high level of parental education and a high level of education of the respondents, to examine similarities in the choice of education between parent and child and to investigate whether parents impose their wishes and ideas on their children regarding their educational choices.

In accordance with the objectives, the following hypotheses are set:

$\mathrm{H} 1$ : Socio-economic status of parents influences student educational aspirations.

$\mathrm{H} 2$ : The student has chosen the same field of study as the parent(s).

H3: There is a positive correlation between parents who read books every day and students who have also built reading habits.

\subsection{Method and Sample}

The research was conducted using a survey method on a convenient sample of 203 students aged 18 to 22 years. These include first and second year students from different faculties: Faculty of Medicine (40), Faculty of Philosophy (35), Department of Health Studies (27), Faculty of Science (20), private faculties (12), Faculty of Economics (11), Department of Professional Studies (11), Faculty of Kinesiology (9), Faculty of Electrical Engineering, Mechanical Engineering and Naval Architecture (9), Academy of Arts (9), Faculty of Education and Rehabilitation (7), Faculty of Maritime Studies (6), Faculty of Chemistry and Technology 5) and the Faculty of Civil Engineering, Architecture and Geodesy (2). The sample included 145 women $(71,4 \%)$ and 58 $(28,6 \%)$ men.

The epidemiological situation regarding the COVID-19 affected the planned number of respondents $(\mathrm{N}=300)$. However, in accordance with the new measures, it was not appropriate or possible to conduct research face to face at the universities, so the survey was transferred to online form (Google Forms) and conducted during June, July and August 2020.

\subsection{Sociodemographic Characteristics of Respondents}

Out of 203 respondents, $112(55,2 \%)$ attended high school (gymnasium) and 91 (44,8\%) attended a fouryear vocational high school. Respondents mostly (45\%) finished high school with excellent and very good grades $(33 \%)$. When it comes to choosing a faculty based on gender, the highest percentage of female respondents chose the Faculty of Philosophy, then the Department of Health Studies and the Faculty of Medicine. The majority of male respondents are students of the Faculty of Medicine, then from Faculty of Philosophy and the Academy of Arts.

Of the total number of respondents, $65 \%$ of them have a father who is still employed, while $15 \%$ of fathers are unemployed and $19 \%$ are retired. Of the fathers who are employed, $35,5 \%$ work in a private company, $31 \%$ in a state-owned company, and $8,4 \%$ own their own company. Respondents' mothers are employed in 
a higher percentage (72\%). $26 \%$ of them are unemployed and only $1 \%$ are retired. Employed mothers mostly work in state-owned companies (34\%), while 31\% are employed in private companies and $9 \%$ of mothers own their own company.

Approximately one third (31\%) of respondents live in a household with a monthly income of between 1,500 and 2,000 euros, while a quarter (25\%) have an income of 1,000 euros and $21 \%$ of them between 500 and 1,000 euros. The majority of respondents (83\%) live in a family that owns their own apartment, while $8 \%$ live in a tenancy and $8 \%$ in a family that owns their own house. During the period of study, $65 \%$ of respondents live at home with their parents, $15 \%$ in a dormitory, $12 \%$ alone in a rented apartment and $7 \%$ with a roommate in a rented apartment. At the same time, $45 \%$ of respondents work part-time, while $37 \%$ do not work at all during studying. Only $16 \%$ of respondents continuously has paid work during etending the faculty. Approximately one third (30\%) of respondents receive an allowance from their parents and at the same time earn from student work, $25 \%$ receive a scholarship, $24 \%$ depend entirely on parental allowance, $17 \%$ earn their money and do not receive pocket money from their parents, and a few (3\%) combines scholarship and pocket money. More than half $(66 \%)$ of respondents perceives their financial situation as neither better nor worse regarding rest of the population ie considering it as average. Still, $24 \%$ of respondents think they live slightly better than most of people, while $4 \%$ think their standard is slightly worse than average. There is also same percentage (2\%) of those who estimate that they live much better than the majority and those who think that they live much worse than the rest of the population (2\%).

\section{RESULTS}

In accordance to the subject of this research, we were interested in the educational structure of the parents of the surveyed students. According to the results of the survey, more than half $(51,2 \%)$ of respondents' fathers finished secondary vocational school, slightly less than a third $(29,6 \%)$ graduated at college or university, $11,8 \%$ fathers are with a high school diploma, $4,9 \%$ with a master's degree or doctorate, $2 \%$ completed only primary school, and $0,5 \%$ didn't complete primary school. The educational structure of mothers is similar $-48,3 \%$ of respondents' mothers are with a high school diploma, $28,6 \%$ with a college or university degree, $15,3 \%$ with a high school diploma, 5,4\% of mothers have a master's or doctoral degree, $2 \%$ of them finished primary school, and also as in the case of fathers, $0,5 \%$ didn't without complete primary school.

Pearson's correlation test showed a positive relationship $(p=0,030)$ of father education as well as a positive relationship $(p=0,017)$ of mother education on student's educational aspirations (taking exams on time, before or during the summer exam period), which confirms hypothesis $\mathrm{H} 1$, which assumes that the socioeconomic status of parents affects the educational aspirations of students.

Table 1. Correlation of father's education with student's habits of passing exams

\begin{tabular}{|l|l|c|c|}
\hline \multicolumn{2}{|l|}{} & FATHER'S EDUCATION & $\begin{array}{c}\text { STUDENT'S HABITS OF } \\
\text { PASSING EXAMS }\end{array}$ \\
\hline \multirow{2}{*}{ FATHER'S EDUCATION } & $\begin{array}{l}\text { Pearson } \\
\text { Correlation }\end{array}$ & 1 &,$- 152^{*}$ \\
\cline { 2 - 4 } & $\begin{array}{l}\text { Sig. (2- } \\
\text { tailed) }\end{array}$ & & $\mathbf{0 , 0 3 0}$ \\
\cline { 2 - 4 } & $\mathrm{N}$ & 203 & 203 \\
\hline \multirow{2}{*}{$\begin{array}{l}\text { STUDENT'S HABITS OF } \\
\text { PASSING EXAMS }\end{array}$} & $\begin{array}{l}\text { Pearson } \\
\text { Correlation }\end{array}$ &,$- 152^{*}$ & 1 \\
\cline { 2 - 4 } & $\begin{array}{l}\text { Sig. (2- } \\
\text { tailed) }\end{array}$ & $\mathbf{0 , 0 3 0}$ & \\
\cline { 2 - 4 } & $\mathrm{N}$ & 203 \\
\hline
\end{tabular}


Table 2. Correlation of mother's education with student's habits of passing exams

\begin{tabular}{|l|l|c|c|}
\hline \multicolumn{2}{|l|}{} & $\begin{array}{c}\text { STUDENT'S HABITS } \\
\text { OF PASSING EXAMS }\end{array}$ & MOTHER'S EDUCATION \\
\hline $\begin{array}{l}\text { STUDENT'S HABITS } \\
\text { OF PASSING EXAMS }\end{array}$ & $\begin{array}{l}\text { Pearson } \\
\text { Correlation }\end{array}$ & 1 &,$- 168^{*}$ \\
\cline { 2 - 4 } & Sig. (2-tailed) & & 0,017 \\
\cline { 2 - 4 } & $\mathrm{N}$ & 203 & 203 \\
\hline \multirow{2}{*}{$\begin{array}{l}\text { FATHER'S } \\
\text { EDUCATION }\end{array}$} & $\begin{array}{l}\text { Pearson } \\
\text { Correlation }\end{array}$ &,$- 168^{*}$ & 1 \\
\cline { 2 - 4 } & Sig. (2-tailed) & $\mathbf{0 , 0 1 7}$ & \\
\cline { 2 - 4 } & $\mathrm{N}$ & 203 & 203 \\
\hline \multirow{2}{*}{ *. Correlation is significant at the 0.05 level (2-tailed). } & \\
\hline
\end{tabular}

Regarding the field of parents' education, the majority of fathers $(52,7 \%)$ were educated in the field of technical sciences, which confirms the thesis that gender differences still exist in the choice of high school, studies and career. Furthermore, $20,7 \%$ of respondents' fathers are educated in the social sciences and humanities, $15,3 \%$ in the medical, $6,9 \%$ natural, and $4,4 \%$ in the arts. The largest percentage $(38,9 \%)$ of mothers are educated in the social sciences and humanities, in technical sciences $(23,6 \%)$, natural sciences $(20,7 \%)$, medical sciences $(8,9 \%)$ and arts $(7,9 \%)$.

The habit of reading books and the amount of books in the family home seems insignificant at first glance, but according to many research, they proved to be very important factors in describing the socio-economic status. According to this research, respondents do not have the habit of reading books frequently. The vast majority of respondents $(72,4 \%)$ read from zero to five books in the last 12 months, $19,7 \%$ of respondents from six to ten books, and 7,9\% of respondents read more than 10 books in the last 12 months (excluding literature and materials for exams). Accordingly, we were interested in the number of books in their household. Data show that less than half of respondents $(41,4 \%)$ have 26 to 100 books in the household, slightly more than a third (36,5\%) estimate that the number ranges between 11 and 25 books, while $15,8 \%$ of respondents consider that there are more than 100 books in their household.

The correlation test showed a positive correlation $(p=0,002)$ between the number of books in the household and the number of books read. The test indicates a trend according to which, the greater the number of books in the household, the more frequent the habit of reading books. However, in the case of this research, due to the smaller number of books that the household contained, the habit of reading books is also weaker.

Table 3. Correlation of the number of books in the household with the number of read books by students

\begin{tabular}{|l|l|c|c|}
\hline \multicolumn{2}{|c|}{} & NUMBER OF BOOKS & READ BOOKS \\
\hline $\begin{array}{l}\text { NUMBER OF } \\
\text { BOOKS }\end{array}$ & $\begin{array}{l}\text { Pearson } \\
\text { Correlation }\end{array}$ & 1 &, $215^{* *}$ \\
\cline { 2 - 4 } & $\begin{array}{l}\text { Sig. (2- } \\
\text { tailed) }\end{array}$ & & $\mathbf{0 , 0 0 2}$ \\
\cline { 2 - 4 } & N & 203 & 203 \\
\hline \multirow{2}{*}{ READ BOOKS } & $\begin{array}{l}\text { Pearson } \\
\text { Correlation }\end{array}$ &, $215^{* *}$ & 1 \\
\cline { 2 - 4 } & Sig. (2- & $\mathbf{0 , 0 0 2}$ & \\
\hline
\end{tabular}




\begin{tabular}{|l|l|c|c|}
\hline & tailed) & & \\
\cline { 2 - 4 } & $\mathrm{N}$ & 203 & 203 \\
\hline$* *$. Correlation is significant at the 0.05 level (2-tailed). \\
\hline
\end{tabular}

If the reading habits of the respondents are compared with the reading habits of the parents, the correlation test does not show a significant correlation. $22,6 \%$ of respondents agree ${ }^{1}$ with the statement that they can see their parents every day with a book in hand. At the same time, $49,8 \%$ of respondents do not agree ${ }^{2}$ with the above. Since the correlation test did not show a significant correlation between the two variables, hypothesis $\mathrm{H} 3$ is rejected because no correlation is found between parents who read books every day and students who have also built reading habits.

Table 4. Correlation test of the frequency of reading books by students and by parents

\begin{tabular}{|l|l|r|r|}
\hline \multicolumn{2}{|c|}{} & \multicolumn{1}{|c|}{$\begin{array}{c}\text { STUDENTS' } \\
\text { READING }\end{array}$} & $\begin{array}{c}\text { PARENTS' } \\
\text { READING }\end{array}$ \\
\hline $\begin{array}{l}\text { STUDENTS' } \\
\text { READING }\end{array}$ & $\begin{array}{l}\text { Pearson } \\
\text { Correlation }\end{array}$ & 1 &, $118^{* *}$ \\
\cline { 2 - 4 } & Sig. (2-tailed) & 203 & 203 \\
\cline { 2 - 4 } & $\mathrm{N}$ &, $118^{* *}$ & 1 \\
\hline \multirow{3}{*}{$\begin{array}{l}\text { PARENTS' } \\
\text { READING }\end{array}$} & $\begin{array}{l}\text { Pearson } \\
\text { Correlation }\end{array}$ & 0,094 \\
\cline { 2 - 4 } & Sig. (2-tailed) & & \\
\cline { 2 - 4 } & $\mathrm{N}$ & 203 & \\
\hline \multirow{2}{*}{${ }^{* *}$. Correlation is significant at the 0.05 level (2-tailed). } \\
\hline
\end{tabular}

Since we wanted to examine the educational aspirations related to the choice of a particular faculty, we offered the respondents the following statements: "I always knew which faculty I would enroll in"; "I enrolled the faculty immediately after finishing high school" and "I decided on a certain faculty during high school. The obtained data show that slightly more than a third $(35,5 \%)$ of the respondents chose the faculty immediately after graduating from high school, which points to the lack of excessive preparations for the faculty during high school. However, $32,5 \%$ of respondents decided to go to college during high school, and there is a similar percentage $(32 \%)$ of those who always knew which college to enroll in. In this regard, we were interested in who had the greatest influence on them regarding the selection of the faculty. According to the data, family or their parents had the greatest influence on a quarter $(24,1 \%)$ of respondents, while $10,8 \%$ of respondents said that their decision was influenced by social circumstances. A tenth $(9,9 \%)$ the respondents were influenced by friends. However, it should be noted that approximately half $(48,8 \%)$ of respondents emphasize that no one particularly influenced their choice of faculty and study program. We were also interested in the extent to which parents influenced the choice of faculty. The results show that $73,4 \%$ of respondents do not agree with the statement that the direction of the faculty was chosen because of parents. On the other hand, a certain number of respondents $(9,9 \%)$ agree with this statement, while there is $16,7 \%$ of those who cannot estimate the answer to the question.

Furthermore, $16,8 \%$ of respondents state that it was extremely difficult for them to decide which faculty to enroll in, while for more than half $(55,6 \%)$ of respondents this choice was not difficult or problematic. Regarding the satisfaction with the choosen faculty, $75,3 \%$ of respondents are satisfied with the chosen programme of the faculty. Only $6,9 \%$ of respondents are dissatisfied with the chosen faculty. Also, the majority $(72,5 \%)$ of respondents state that their parents agree with their choice of the faculty, while there is

\footnotetext{
${ }^{1}$ For interpretation, the categories "I generally agree" and "I completely agree" are added together.

2 For interpretation, the categories "mostly disagree" and "completely disagree" are added together.
} 
$9,9 \%$ of those whose parents do not support their choice. Considering that we were interested in the influence of socio-economic status on students' educational aspirations, the respondents were asked whether in the near future they saw themselves in the same profession as their parents. Since the majority $(70,9 \%)$ of respondents do not want to pursue the same occupation as their parents, H2 hypothesis, which assumed that the student would choose the same occupation as the parent(s), is rejected. Despite this, $81,3 \%$ of respondents point out that their parents support them in everything they do.

Regarding the habit of taking exams, as many as $88 \%$ of respondents took their exams before or during the summer term, while $11 \%$ of them decided to take the exams in autumn terms. Furthermore, $79,8 \%$ of respondents intend to enroll in a graduate level after the undergraduate level which they attended during the research. Regarding the opportunity of finding a job after graduation, slightly less than half $(41,4 \%)$ of respondents think that they have a secure job, while $29,6 \%$ are not very optimistic. Also, $30 \%$ of respondents cannot estimate the answer to this question.

\section{CONCLUSION}

Socio-economic status is an extremely complex concept that includes a significant number of indicators that make it up, but also that affect the environment, and primarily the descendants of parents. In this sense, its influence on children's educational aspirations is indispensable. The most important predictors of educational success are most often family income and the education and occupation of parents, which show the extent to which the student has access to the material resources needed to succeed in school. A significant number of studies have confirmed the persistence of the relationship between socioeconomic status and educational attainment as well as the assumption that parental education is one of the most stable predictors of education showing that children of more educated parents ultimately perform better and achieve higher grades in school.

This paper presents the results of a research aimed at examining the impact of socioeconomic status of parents on students' educational aspirations. The obtained results indicate the existence of latent socioeconomic impact in terms of the level of education of both fathers and mothers, with a higher level of education of parents associated with a more positive attitude towards university obligations and desires for continuing education. The data also show that the division into male-female occupations is still present in society, with a high percentage of fathers who were educated in technical occupations, while mothers were mostly educated in the field of social sciences and humanities. At the same time, it is shown that there is a correlation between the number of books in the home library and the total number of books that students read, but the number of books read is not related to the parent's reading habit. Students are divided in their opinions regarding the selection of faculty, with almost equal numbers of those who chose college immediately after high school, those who knew their choice during high school, and those who always knew which college they wanted to enroll in. For half of the respondents, choosing the desired faculty was not problematic, and most students and their parents are satisfied with the choice of faculty. Students take exams mostly during the summer exam period and intend to enroll in graduate studies. However, most respondents do not see themselves in the same occupation as their parents. Finally, according research results we can conclude that there is no direct intrusive influence of parents on respondents' decisions regarding study.

\section{REFERENCE LIST}

Baranović, B., Jugović, I., Puzić, S. (2014). Važnost obiteljskog podrijetla i roda za uspjeh iz matematike i odabir srednje škole. Revija za socijalnu politiku, 21(3): 285-307. https://doi.org/10.3935/rsp.v21i3.1174

Burušić, J., Babarović, T., Marković, N. (2010). Koliko daleko padaju jabuke od stabla? Odnos obrazovnih postignuća djece i obrazovne razine njihovih roditelja. Društvena istraživanja, 19(4-5): 709-730.

Baucal, A. (2012). Uticaj socio-ekonomskog statusa učenika na obrazovna postignuća: direktni i indirektni uticaji, Univerzitet u Beogradu, Filozofski fakultet, Odeljenje za psihologiju, primenjena psihologija, pp. 5-24.

Bedeniković Lež, M. (2009). Uloga majke u školskom uspjehu djeteta. Školski vjesnik: časopis za pedagogijsku teoriju i praksu, 58(3): 331-344. 
Chen, Q., Kong, Y., Gao, W., Mo, L. (2018). Effects of Socioeconomic Status, Parent-Child Relationship, and Learning Motivation on Reading Ability. Frontiers in Psychology. 9: 1297.doi: 10.3389/fpsyg.2018.01297

Đurić, B. (2015). Socioekonomski status roditelja i školski uspjeh učenika. Diplomski rad. Rijeka: Filozofski fakultet SSveučilišta u Rijeci.

Gregurović, M., Kuti, S. (2010). Učinak socioekonomskog statusa na obrazovno postignuće učenika: Primjer PISA istraživanja, Hrvatska 2006. Revija socijalne politike, 17 (2): 179-196.

Ivanović, M., Rajić-Stojanović, I. (2012). Povezanost socioekonomskog statusa roditelja i profesionalnih namjera učenika osmih razreda osnovne škole. Hrvatski zavod za zapošljavanje. https://cisok.hr/wpcontent/uploads/2019/05/Ivanovic\%CC\%81-Rajic\%CC\%81-Stojanovic\%CC\%81_Povezanostsocioekonomskog-statusa-roditelja-i-profesionalnih-namjera-uc\%CC\%8Cenika-2012.pdf

Lee, V. E., Burkam, D. T. (2002). Inequality at the starting gate: social background differences in achievement as children begin school. Washington: Economic Policy Institute.

Li, Z., Qiu, Z. (2018). How does family background affect children's educational achievement? Evidence from Contemporary China. The Journal of Chinese Sociology, 5, 13: 1-21. https://doi.org/10.1186/s40711018-0083-8

Miljević-Riđički, R., Pahić, T., Vizek-Vidović, V. (2011). Suradnja roditelja i škole u Hrvatskoj: sličnosti i razlike urbanih i ruralnih sredina. Sociologija i prostor, 49(2): 165-184.

Pavić, Ž., Vukelić, K. (2009). Socijalno podrijetlo i obrazovne nejednakosti: istraživanje na primjeru osječkih studenata i srednjoškolaca. Revija za sociologiju, 40(1-2): 53-70.

Rajeswari, K. V., Usha, P. (2014). Socioeconomic status and parental Involvement: a Comparison among Tribal, Fisherfolk and Muslim majority Secondary Schools of Kerala. IOSR Journal of Humanities And Social Science, 19(5):51-56.

Šimić Šašić, S., Klarin, M., Proroković A. (2011). Socioekonomske prilike obitelji i kvaliteta obiteljske interakcije kao prediktori školskog uspjeha srednjoškolaca u Hrvatskoj, Bosni i Hercegovini i Makedoniji. Ljetopis socijalnog rada, 18 (1): 31-62, Sveučilište u Zadru.

Škorokov, L. (2014). Uloga socioekonomskog statusa obitelji u objašnjenju internaliziranih i eksternaliziranih problema i školskog uspjeha kod mladih adolescenata. Diplomski rad. Zadar: Odjel za psihologiju Sveučilišta u Zadru, 